\title{
PERANCANGAN SISTEM INFORMASI INVENTORY BARANG PADA TOKO BUMEN REPRO JAKARTA PUSAT
}

\author{
Devia Andarista ${ }^{1}$, Aswin Fitriansyah ${ }^{2}$, Randi Ramliyana ${ }^{3}$ \\ 1,2,3 Informatika Universitas Indraprasta PGRI \\ Jalan Raya Tengah No 80, Kelurahan Gedong, Pasar Rebo, Jakarta Timur \\ 1deviaandarista367@gmail.com, ${ }^{2}$ aswin.fitriansyah@gmail.com, ${ }^{3}$ Randi.ramliyana@gmail.com
}

\begin{abstract}
ABSTRAK
Penelitian ini adalah untuk mengetahui seperti apa sistem yang digunakan dalam pengolahan data Inventory yang ada pada Toko Bumen Repro serta kendala yang dihadapi terhadap sistem tersebut. Dengan penerapan aplikasi ini diharapkan dapat mempermudah karyawan dalam bekerja dengan lebih baik dan lebih cepat dalam menginput serta dalam proses transaksi penjualan dan pembelian. Perancangan ini adalah metode kualitatif deskriptif yaitu metode penelitian yang melakukan pengamatan terhadap objek penelitian yang menghasilkan suatu konsep atau teori baru terhadap eksperimen seperti: observasi, wawancara dan studi literatur serta pengumpulan data untuk pengujian suatu penelitian untuk dasar pengambilan keputusan terhadap eksperimen seperti pengembangan sistem yang akan dibuat. Selama melakukan penelitian ini penulis menemukan bahwa pada Toko Bumen Repro memerlukan suatu sistem yang terkomputerisasi dengan efektif dan efisien sehingga dapat membantu pekerjaan para pegawainya dalam melakukan pengolahan data Inventory, serta kurangnya sumber daya manusia yang paham mengenai sistem informasi. Oleh sebab itu penulis mencoba membuat suatu sistem yaitu sistem Invenrtory menggunakan bahasa pemrograman Java dan MySQL sebagai database. Penelitian ini menghasilkan aplikasi inventory barang berbasis dekstop yang mempermudah pengelola dalam melakukan pendataan barang.
\end{abstract}

Kata Kunci: Sistem Informasi, Inventory, Java

\begin{abstract}
The purpose of this study is to find out what kind of system used in processing existing Inventory data at the Bumen Repro store. As well as obstacles faced by the system. The application of this application is expected to facilitate employees in working better and more quickly in inputting and in the process of sales and purchases. In addition, the authors hope that readers can understand the use of an application system, especially the Inventory system. The research method used in this design is a descriptive qualitative method that is a research method that observes the research object that produces a new concept or theory of experiments such as: observation, interviews and literature studies as well as collecting data for testing a study for the basis of decision making on experiments such as the development of the system to be made. During doing this research the writer found that the Bumen Repro store needed a computerized system that was effective and efficient so that it could assist the work of its employees in processing Inventory data, as well as the lack of human resources who understood information systems. Therefore the authors try to make a system that is an Invenrtory system using the Java programming language and MySQL as a database. This research produces desktop-based goods inventory applications that make it easier for managers to collect goods.
\end{abstract}

Key Word: Information Systems, Inventory, Java.

\section{PENDAHULUAN}

Perkembangan teknologi informasi saat ini berkembang dengan sangat pesat dan masuk kedalam berbagai aspek-aspek kehidupan yang ada. Segala jenis kegiatan manusia pada saat ini tidak terlepas dari penggunaan alatalat dalam bidang teknologi informasi. Bidang kesehatan, militer dan perdagangan kini tidak terlepas dari penerapan berbagai macam teknologi informasi. Penerapan teknologi informasi di berbagai bidang tersebut dapat memudahkan pekerjaan yang ada serta lebih menghemat waktu. Meskipun di Indonesia perkembangan teknologi masih dalam tahap awal perkembangan, namun jika dilihat dari jumlah penduduk serta jumlah usia produktif yang ada maka dapat dilihat bahwa peluang yang ada di indonesia sangat menjanjikan.

Pada proses pengolahan data sistem inventory dan penjualan di Toko Bumen Repro masih belum mengunakan sistem yang terkomputerisasi, dalam pendataan stok inventory dan transaksi penjualan pada Toko Bumen Repro masih dilakukan secara manual dengan mencatat di sebuah buku tulis.

Berdasarkan pada permasalahan diatas penulis bermaksud membuat skripsi dengan 
judul "Perancangan Sistem Informasi Inventory Barang pada Toko Bumen Repro Jakarta". Dengan tujuan adanya sistem inventory dan penjualan barang dapat memudahkan Toko Bumen Repro dalam pendataan dan penjualan sehingga menjadi lebih cepat dan akurat.

Berdasarkan latar belakang masalah diatas penulis dapat mengambil kesimpulan tentang identifikasi masalah, yaitu:

1. Proses peralatan data inventory data penjualan masih menggunakan cara tulis tangan sehingga rawan terjadi kesalahan pencatatan.

2. Proses pembuatan laporan memakan waktu lama dan masih berupa pembukaan arsip.

3. Dalam proses transaksi penjualan barang, perhitumgan harga masih menggunakan cara konvensional sehingga membutuhkan waktu lama dalam setiap transaksi.

Adapun tujuan yang ingin dicapai dalam Perancangan Sistem Peminjaman Buku Pada Toko Bumen Repro adalah untuk mengetahui proses pengolahan data pada Bumen Repro dan untuk merancang sistem data penjualan dan data inventory yang dapat membantu saat terjadi trasaksi dan pengolahan data barang.

Sebuah sistem terdiri dari atas bagian-bagian yang bergabung untuk suatu tujuan tertentu. Sebuah sistem bisa terdiri dari bagian-bagian yang saling berkaitan yang beroperasi bersama untuk mencapai sasaran, maksud atau tujuan tertentu (Isnandi \& Wardati, 2014).

Sistem adalah suatu kesatuan usaha yang terdiri dari bagian-bagian yang berkaitan satu sama lain yangberusaha mencapai suatu tujuan dalam suatu lingkungan kompleks. Pengertian tersebut mencerminkan adanya beberapa bagian dan hubungan antara bagian, ini menunjukkan kompleksitas dari sistem yang meliputi kerja sama antara bagian yang independent satu sama lain (Sunoto \& Susanto, 2017).

Informasi merupakan hasil pemrosesan data (fakta) menjadi sesuatu yang bermakna dan bernilai untuk pengambilan keputusan (Wongso, 2015).
Informasi adalah salah satu kata kunci salah satu kunci pada zaman ini. Untuk mendapatkan dan menghasilkan informasi, komputer dan teknologinya adalah salah satu alat bantu yang paling tepat (Utama, 2018).

Sistem informasi adalah proses pengolahan data sehingga mempunyai makna lebih yang dapat digunakan oleh pimpinan dalam mengambil keputusan (Haqi \& Setiawan, 2017).

Sistem Informasi dapat merupakan gagasan dari suatu deretan berkas yang dibuat menyatakan sumber terstruktur atau didesain dan alasan atau tuntutan untuk struktur ini. Perkembangan atau modifikasi dari sistem informasi sering diistilahkan sebagai suatu projek. Projek dapat ditelaah sebagai lingkaran kehidupan, yang dalam kasus sistem informasi, dapat dibagi ke dalam empat fase. Sistem inventory merupakan suatu sistem untuk mengetahui persediaan stok barang pada suatu tempat. Sistem inventory sudah banyak digunakan atau dikembangkan pada suatu tempat dengan berbagai macam teknologi dan sistem (A. Wijoyo, 2020).

Sistem informasi inventory merupakan sebuah hal keharusan yang harus dimiliki sebuah perusahaan ataupun usaha yang bergerak pada bidang penjualan dan pembelian agar dapat mengolah data transaksi yang berkaitan dengan persedian dapat dilakukan secara efektif dan efisien (Muflihin et al., 2020).

Sistem inventory adalah bagian yang disediakan dalam proses yang terdapat dalam suatu perusahaan untuk di produksi, serta barang jadi yang di sediakan untuk memenuhi permintaan dari konsumen setiap waktu yang disimpan dan di rawat menurut aturan tertentu dalam keadaan siap pakai dan tersimpan dalam database (Fahrisal et al., 2019).

Sistem Informasi Inventory merupakan sebuah sisten informasi yang mengelola manajemen atau pengelolaan inventory yang ada dalam suatu organisasi. Pada dasarnya semua organisasi membutuhkan sistem informasi inventory karena setiap organisasi pasti mempunyai barang-barang inventaris yang harus dikelola (Rahmadi \& Yusmiarti, 2017). 
Java merupakan bahasa yang powerfull yang bisa digunakan dalam hampir semua bentuk pengembangan software. Anda dapat menggunakan java untuk membuat game, aplikasi dekstop, aplikasi web, aplikasi enterprise, aplikasi jaringan, dan lain-lain. Yang menarik adalah bahwa java bias digunakan untuk membuat laporan yang dapat berjalan di atas HP, PDA, dan peralatan lain yang dilengkapi dengan Java Virtual Machine(JVM) (Isnandi \& Wardati, 2014).

Java adalah bahasa pemrograman dan platform komputasi pertama kali dirilis oleh Sun Microsystems pada tahun 1995. Java merupakan teknologi yang mendasari kekuatan program untuk utilitas, permainan, dan aplikasi bisnis (Yuana, 2015).

Berdasarkan latar belakang tersebut, menyoroti mengenai betapa pentingnya penerapan teknologi informasi pada Toko Bumen Repro, maka penulis melakukan penelitian yang berkaitan dengan sistem informasi inventory barang pada Toko Bumen Repro Jakarta Pusat Berbasis Java Netbens untuk mengetahui proses pengolahan data pada Bumen Repro.

\section{METODE PENELITIAN}

Tempat Penelitian dilakukan di Bumenrepro yang beralamat di Kali baru barat No.32 RT.002 RW.01 Bungur Kecamatan Senen Jakarta Pusat, sedangkan waktu penelitian berlangsung dari bulan Januari sampai bulan April 2021. Dalam melakukan penelitian diperlukan adanya suatu penelitian supaya dapat disusun sesuai dengan pokok permasalahan yang akan diteliti. Metode penelitian merupakan alat yang dapat digunakan untuk melaksanakan suatu penelitian, maka dapat disimpulkan bahwa metode penelitian adalah suatu teknik atau cara mencari, memperoleh, mengumpulkan atau mencatat data yang dapat digunakan untuk faktor-faktor yang berhubungan dengan pokok permasalahan, sehingga akan dapat suatu kebenaran atas data yang diperoleh.

Metode penelitian yang penulis lakukan bersifat kualitatif deskriptif. Penetian melakukan pengamatan terhadap objek penelitian yang menghasilkan suatu konsep atau teori baru terhadap eksperimen seperti: observasi, wawancara dan studi literatur serta pengumpulan data untuk pengujian suatu penelitian untuk dasar pengambilan keputusan terhadap eksperimen seperti pengembangan sistem yang akan dibuat.

\section{Metode Pengumpulan Data}

Metode pengumpulan data yang dilakukan oleh penulis untuk mendapatkan data - data serta infromasi untuk mendukung penyempurnaan hasil dari penelitian ini antara lain:

1. Studi Kepustakaan

Studi pustaka adalah segala usaha yang dilakukan oleh peneliti untuk menghimpun informasi yang relevan dengan topik atau masalah yang akan atau sedang diteliti. Informasi dapat diperoleh dari buku-buku ilmiah, laporan penelitian, ensiklopedia dan sumbersumber tertulis baik tercetak maupun elektronik lain. Penulis mencari literatur yang berkaitan dengan sistem informasi absensi menggunakan buku-buku dan elektronik.

2. Observasi

Observasi adalah pengamatan dan juga pencatatan sistematik atas unsur-unsur yang muncul dalam suatu gejala atau gejala-gejala yang muncul dalam suatu objek penelitian. Hasil dari observasi akan dilaporkan dalam suatu laporan yang tersusun secara sistematis mengikuti aturan yang berlaku. Sehingga Penulis mempelajari dan mengamati sistem inventory barang yang terdapat di Toko Bumen Repro

3. Wawancara

Wawancara yaitu mendapatkan informasi dengan cara bertanya langsung kepada responden. Tanpa wawancara, peneliti akan kehilangan informasi yang hanya dapat diperoleh dengan jalan bertanya langsung kepada responden. Data semacam itu merupaakn tulang punggung suatu penelitian. Sehingga Penulis dapat mewancarai karyawan di Toko Bumen Repro tentang sistem inventory terdapat di Toko Bumen Repro

\section{HASIL DAN PEMBAHASAN \\ Diagram Alir Data(DAD) Sistem yang Diusulkan}

Berikut ini merupakan gambaran tentang sistem yang diusulkan pada perancangan 
sistem informasi inventory barang pada Toko Bumen Repro Jakarta Pusat berbasis Java Netbeans dalam bentuk diagram konteks:

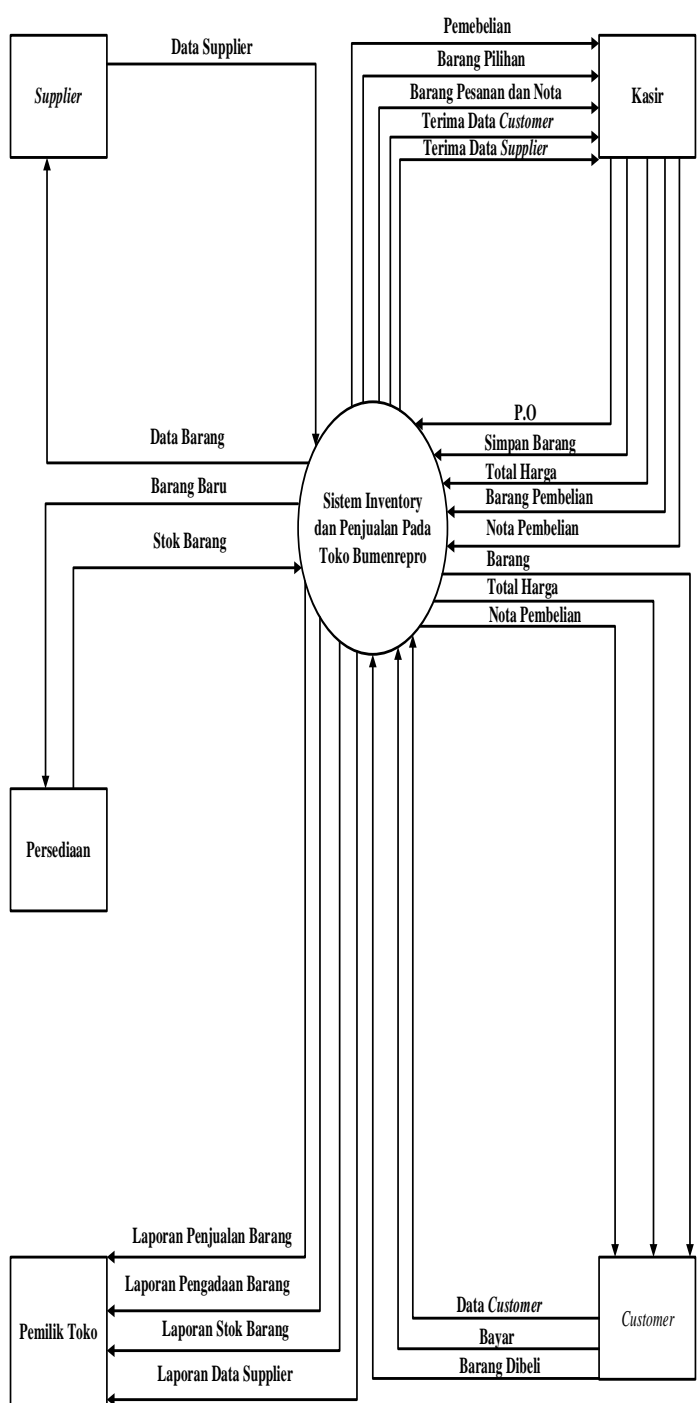

Gambar 1.Diagram Konteks Sistem yang Diusulkan

\section{Entity Relationship Diagram (ERD)}

Berikut ini merupakan gambaran tentang sistem yang diusulkan pada perancangan sistem informasi inventory barang pada Toko Bumen Repro Jakarta Pusat berbasis Java Netbeans dalam bentuk entity relationship diagram:

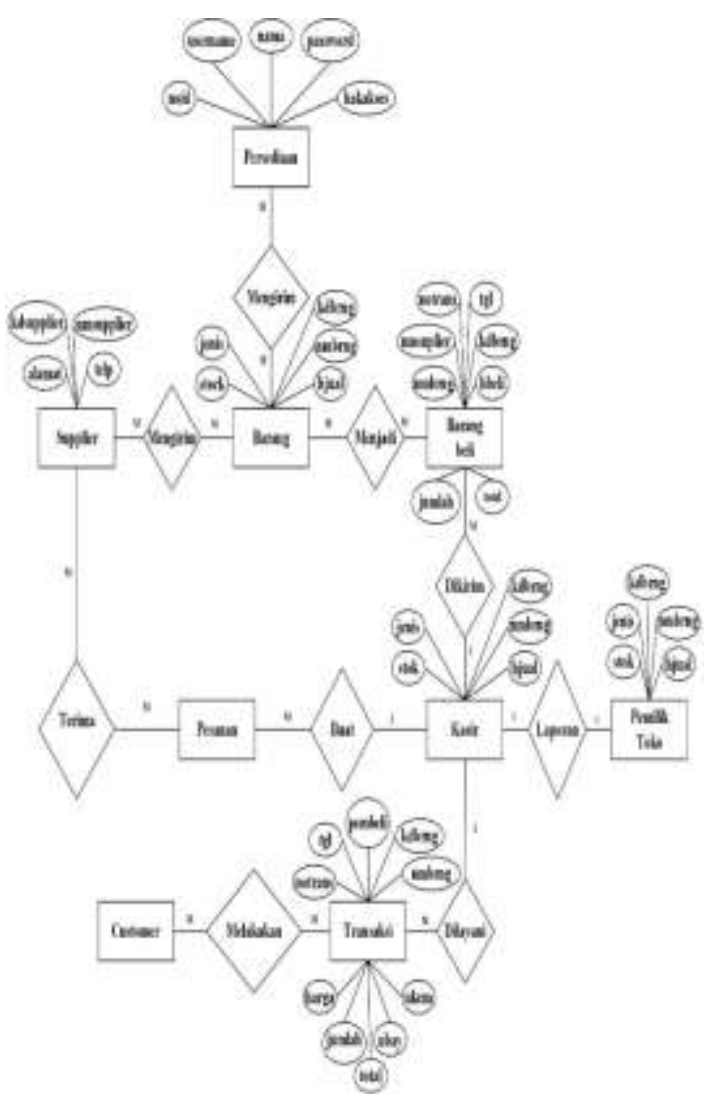

Gambar 2.Entity Relationship Diagram Sistem yang Diusulkan

Tampilan Layar, Tampilan Format Masukan, dan Tampilan Keluaran

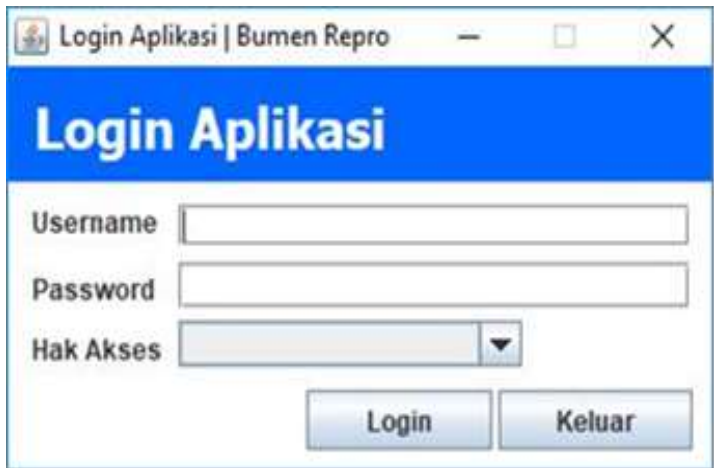

Gambar 3.Tampilan Menu Login

Tampilan login ini muncul di awal saat pengoperasian program. Sebelum pengguna masuk ke menu aplikasi, pengguna wajib mengisi username dan password. Setelah pengguna mengisi username dan password pengguna dapat masuk ke dalam menu aplikasi. 


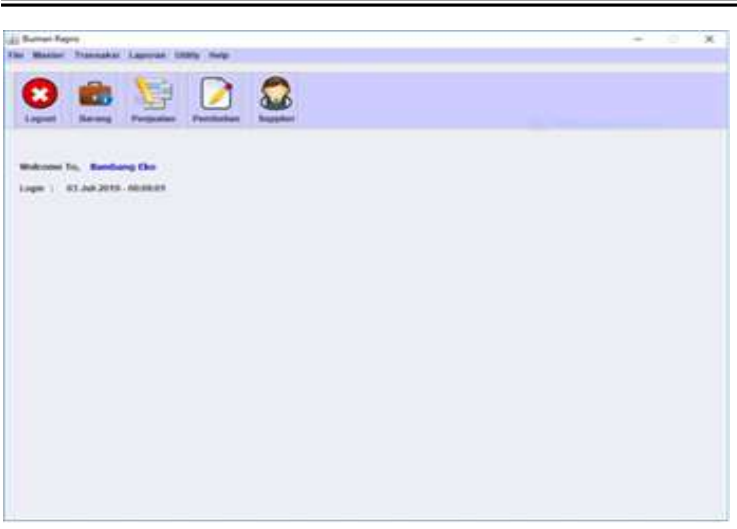

Gambar 4.Tampilan Menu Utama

Tampilan ini merupakan tampilan menu utama program. Pada tampilan menu utama ini tersedia menu logout, barang, penjualan, pembelian, dan supplier. Di dalam menu berkas terdapat data petugas, data barang dan data supplier. Di dalam menu barang terdapat data barang, menu penjualan data penjualan terhadapat data penjualan kepada customer, menu pembelian terdapat pembelian barang kepada supplier, dan di menu supplier terdapat data supplier Toko Bumen Repro. Terdapat juga menu keluar untuk keluar dari program.

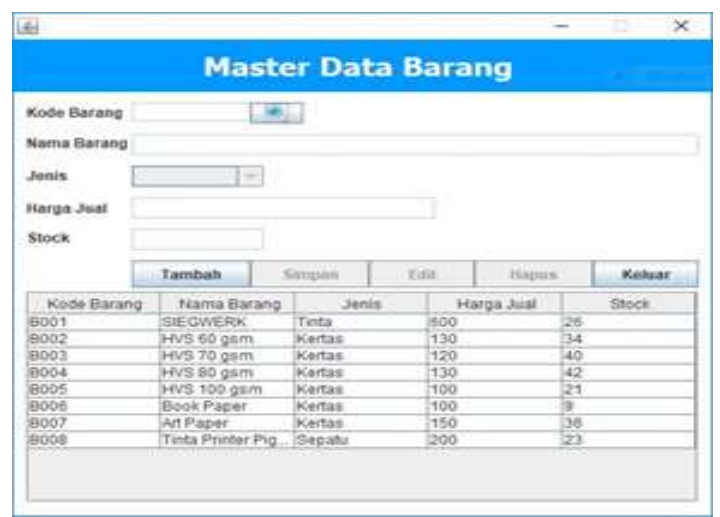

Gambar 5.Tampilan Menu Data Barang

Tampilan ini merupakan tampilan form data barang yang berfungsi untuk mendata stok barang. Pada form ini, pengguna dapat melakukan penambahan data barang baru, menyimpan data, mengubah data, menghapus data dan keluar dari form inputan.

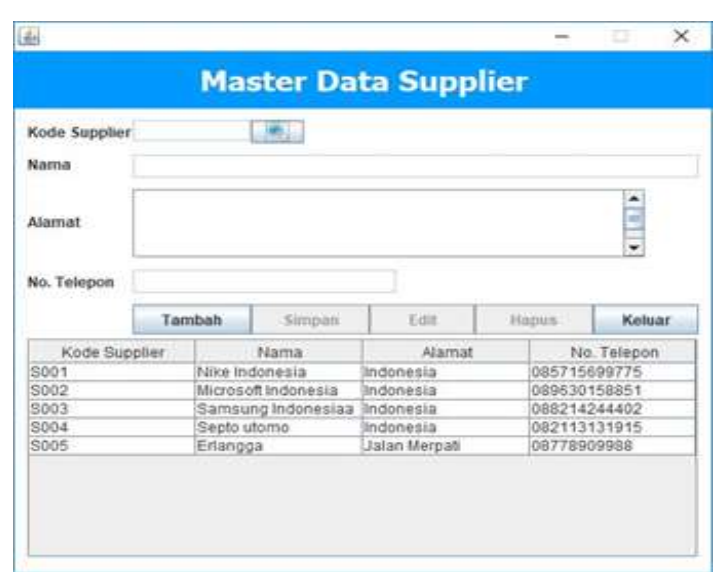

Gambar 6.Tampilan Menu Data Supplier

Tampilan ini merupakan tampilan form data supplier yang berfungsi untuk mendata supplier. Pada form ini, pengguna dapat melakukan penambahan data supplier, menyimpan data, mengubah data, menghapus data dan keluar dari form login.

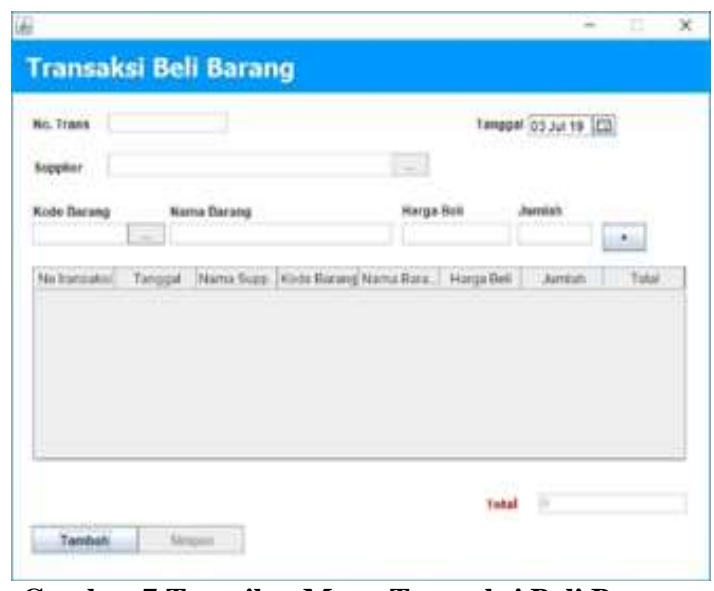

Gambar 7.Tampilan Menu Transaksi Beli Barang

Tampilan ini merupakan tampilan form data Beli Barang yang berfungsi untuk mendata pembelian barang kepada supplier. Pada form ini, pengguna dapat melakukan penambahan menyimpan data pembelian barang.

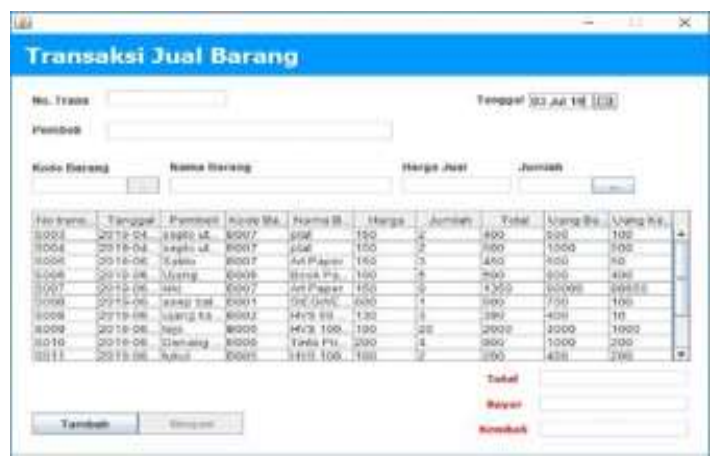

Gambar 8.Tampilan Menu Transaksi Jual Barang 
Tampilan ini merupakan tampilan form data penjualan yang berfungsi untuk mendata data penjualan kepada customer. Pada form ini, pengguna dapat melakukan penambahan data penjualan, dan menyimpan data.

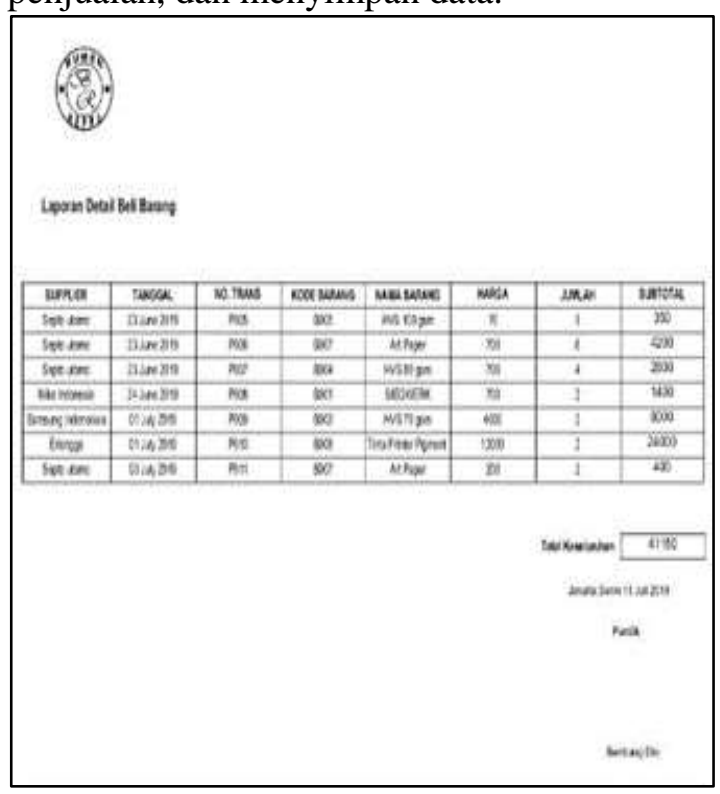

Gambar 9.Tampilan Laporan Beli Barang

Tampilan cetak laporan beli barang ini berisi data-data pembelian barang dari supplier, bertujuan untuk mencetak hasil pendataan pembelian barang.

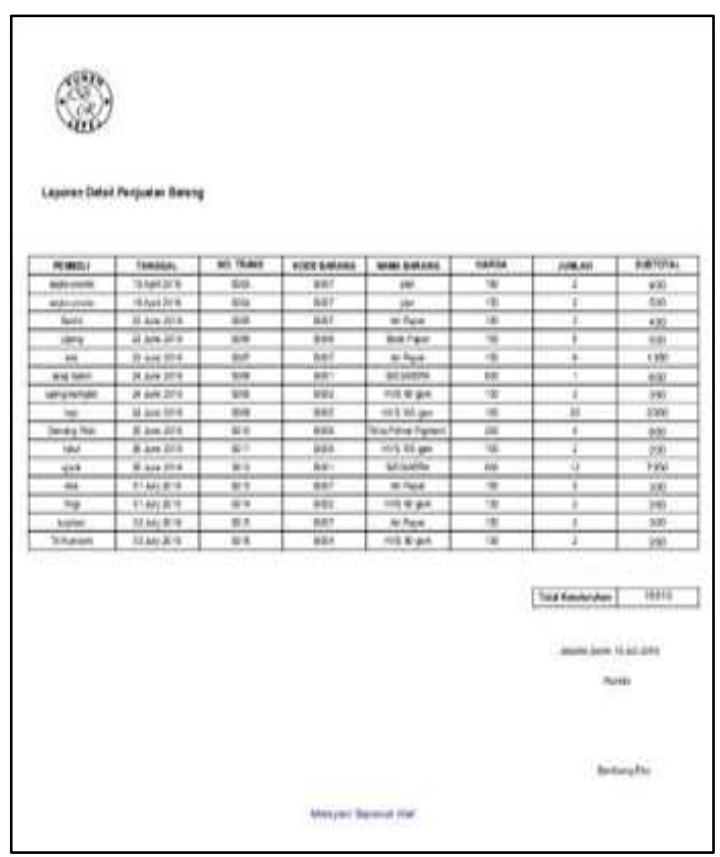

Gambar 10.Tampilan Laporan Jual Barang

Tampilan cetak laporan penjualan barang ini, bertujuan untuk mencetak hasil penjualan barang

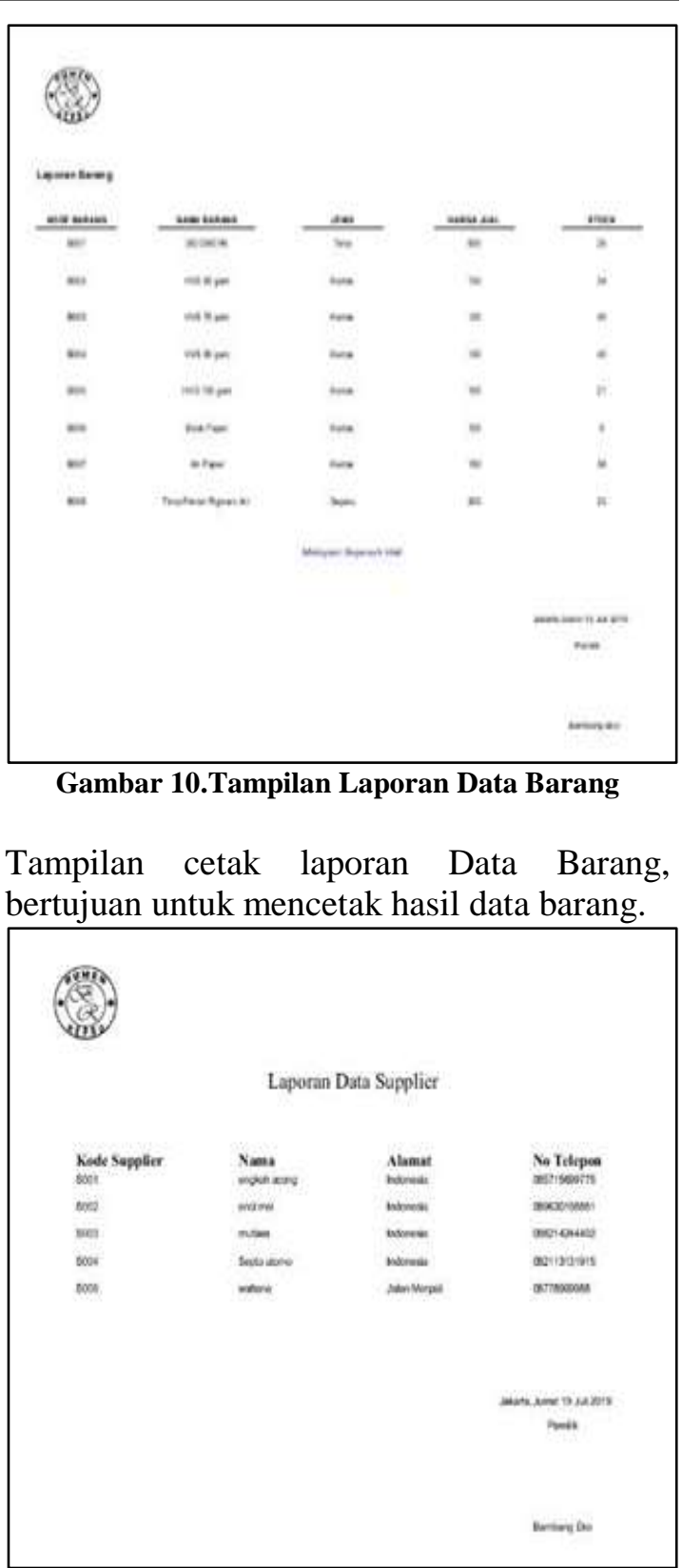

Gambar 11.Tampilan Laporan Data Barang

Tampilan cetak laporan data supplier bertujuan untuk mendata supplier pada Toko Bumen Repro.

\section{SIMPULAN DAN SARAN}

Sistem informasi inventory barang dirancang untuk mempermudah pembuatan laporan jual dan beli barang di Toko Bumen repro secara tepat dan cepat dibandingkan dengan tanpa menggunakan sistem informasi inventory barang.

Sistem informasi inventory barang ini berisikan data barang, data transaksi jual barang, data transaksi beli barang, data supplier, laporan data supplier, laporan data 
barang, laporan data jual barang, laporan data beli barang.

Sistem informasi inventory barang ini diketahui dapat membantu mempermudah pembuatan laporan di Toko Bumen Repro, tetapi karena sistem ini masih dalam pengembangan sehingga belum sepenuhnya sempurna, maka penulis menyarankan untuk dikembangkan sistem informasi inventory lebih lanjut agar dapat digunakan secara lebih baik lagi.

\section{UCAPAN TERIMAKASIH}

Penulis sampaikan rasa terimakasih kepada Toko Bumen Repro sebagai mitra penelitian.

\section{DAFTAR PUSTAKA}

A. Wijoyo, D. H. (2020). Analisis Dan Perancangan Sistem Informasi Inventory Pada Pt Insan Data Permata. Jurnal Riset Dan Aplikasi Mahasiswa Informatika (Jrami).

Fahrisal, F., Pohan, S., \& Nasution, M. (2019). Perancangan Sistem Inventory Barang Pada Ud. Minang Dewi Berbasis Website. Jurnal Informatika. Https://Doi.Org/10.36987/Informatika. V6i2.743

Haqi, B., \& Setiawan, H. S. (2017). Sistem Informasi Pengolahan Data Pendaftaran Siswa Dan Penyusunan Jadwal Kursus Lpia. Seminar Nasional Riset Dan Teknologi (Semnasristek), 63-68.

Isnandi, \& Wardati, I. U. (2014). Sistem Informasi Penjualan Tiket Pada Al Fath Tours Dan Travel Pacitan. Speed Journal - Sentra Penelitian Engineering Dan Edukasi.

Muflihin, H. H., Dhika, H., \& Handayani, S. (2020). Perancangan Sistem Informasi Inventory Pada Toko Rosadah. Bianglala Informatika. Https://Doi.Org/10.31294/Bi.V8i2.8712

Rahmadi, L., \& Yusmiarti, K. (2017). Perancangan Sistem Informasi Inventory Berbasis Web. Seminar Nasional Teknologi Informasi Dan Multimedia 2016.

Sunoto, I., \& Susanto, A. (2017). Sistem Pendukung Keputusan Pemilihan Asuransi Jiwa Menggunakan Metode Analytic Hierarchy Process Dengan Criterium Decision Plus. Jurnal Teknologi.
Https://Doi.Org/10.24853/Jurtek.9.1.712

Utama, Y. (2018). Informasi. Sistem Informasi.

Wongso, F. (2015). Perancangan Sistem Informasi Penjualan Berbasis Java Studi Kasus Pada Toko Karya Gemilang Pekanbaru. Jurnal Ilmiah Ekonomi Dan Bisnis.

Yuana, R. A. (2015). Pemrograman Java. Informatika. 